\title{
Interventional Study Protocol Version Control Type Code
}

National Cancer Institute

\section{Source}

National Cancer Institute. Interventional Study Protocol Version Control Type Code. NCI Thesaurus. Code C93855.

A coded value specifying the kind of comparison or comparator against which the study treatment is evaluated. 